\title{
Determinants of preeclampsia and eclampsia among women delivering in county hospitals in Nairobi, Kenya [version 1;
} peer review: 2 not approved]

\author{
Gorbee G. Logan (D1) Peter K. Njoroge2, Lambert O. Nyabola3, \\ Marshal M. Mweu (iD) \\ ${ }^{1}$ Department of Communicable and Non-communicable Diseases Prevention and Control, School of Public Health, University of \\ Nairobi, Nairobi, Nairobi County, 00100, Kenya \\ 2Department of Family Health, School of Public Health, University of Nairobi, Nairobi, Nairobi County, 00100, Kenya \\ ${ }^{3}$ Department of Biostatistics, School of Public Health, University of Nairobi, Nairobi, Nairobi County, 00100, Kenya \\ ${ }^{4}$ Department of Epidemiology, School of Public Health, University of Nairobi, Nairobi, Nairobi County, 00100, Kenya
}

V1 First published: 18 Mar 2020, 9:192

https://doi.org/10.12688/f1000research.21684.1

Latest published: 18 Mar 2020, 9:192

https://doi.org/10.12688/f1000research.21684.1

\section{Abstract}

Background: Preeclampsia is defined as the onset of a new episode of high blood pressure in a woman usually after 20 weeks gestation plus proteinuria, whereas eclampsia is defined as generalized seizures in a pregnant woman who generally has preeclampsia criteria.

Preeclampsia and eclampsia are hypertensive disorders of pregnancy and thus, among the top causes of maternal death worldwide. The objective of this study was to investigate risk factors for preeclampsia/eclampsia.

Methods: This was a hospital-based unmatched case-control study carried out among women of reproductive age (15-49 years) who have given birth at Nairobi County Hospitals and admitted to the postnatal ward July-September 2019 with a sample size of 352 participants (88 cases and 264 controls). All cases were selected, while controls were simple random sampled, as per eligibility criteria. Information or data were gathered using a structured interviewer-administered questionnaire and data abstraction tool. Descriptive analysis was carried out, where, categorical variables were presented in percentages or proportions, whereas; continuous variables were presented in means, standard deviations, and range. This was followed by a bivariable mixed-effect logistic regression analysis and a multivariable mixed-effect logistic regression analysis using the significant variables from bivariable analysis.

Results: Of all the 88 cases enrolled in the study 5 (5.68\%) had eclampsia and 83 (94.32\%) had preeclampsia. There was a significant association between personal history of hypertension (AOR=7.1;95\% CI: 2.6-19.3, $\mathrm{p}=0.001$ ), Occupation as a housewife (AOR=3.1; 95\% CI: 1.1-8.8, $p=0.034)$, nulliparity $(A O R=7.5 ; 95 \% C I: 1.5-37.5, p=0.015)$,

\section{Open Peer Review

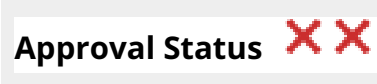 \\ 2 \\ version 1 \\ 18 Mar 2020

$\underset{\text { view }}{X}$ \\ X \\ 1. Ishag Adam (iD), University of Khartoum, Khartoum, Sudan \\ 2. Jussara Mayrink, Federal University of Minas Gerais, Minas Gerais, Brazil}

Any reports and responses or comments on the article can be found at the end of the article. 
primiparity ( $A O R=2.1 ; 95 \% \mathrm{CI}: 1.1-4.2, \mathrm{p}=0.031)$, advanced maternal age $35-49$ years $(A O R=5.9 ; 95 \% \mathrm{CI}: 1.1-33.3, \mathrm{p}=0.042)$, and the occurrence of preeclampsia/eclampsia.

Conclusions: The following conclusions were made regarding the study findings: Personal history of hypertension, older/advanced maternal age (35-49 years), occupation, and parity were factors significantly associated with preeclampsia/eclampsia.

Keywords

Preeclampsia, Eclampsia, Determinants

Corresponding authors: Gorbee G. Logan (gorbeelib@yahoo.com), Peter K. Njoroge (pknjoroge@uonbi.ac.ke), Lambert O. Nyabola ( Inyabola@uonbi.ac.ke), Marshal M. Mweu (marshal@uonbi.ac.ke)

Author roles: Logan GG: Conceptualization, Data Curation, Formal Analysis, Funding Acquisition, Investigation, Methodology, Project Administration, Resources, Software, Supervision, Validation, Visualization, Writing - Original Draft Preparation, Writing - Review \& Editing; Njoroge PK: Investigation, Supervision, Validation, Visualization, Writing - Review \& Editing; Nyabola LO: Formal Analysis, Investigation, Methodology, Supervision, Validation, Visualization, Writing - Review \& Editing; Mweu MM: Formal Analysis, Methodology, Writing - Review \& Editing

Competing interests: No competing interests were disclosed.

Grant information: This research project was supported by the Government of Liberia, Republic of Liberia scholarship (Ref No. $\mathrm{MOH} / \mathrm{GOL} / \mathrm{EBT} / \mathrm{DMA} / 2784 / 17)$.

The funders had no role in study design, data collection and analysis, decision to publish, or preparation of the manuscript.

Copyright: @ 2020 Logan GG et al. This is an open access article distributed under the terms of the Creative Commons Attribution License, which permits unrestricted use, distribution, and reproduction in any medium, provided the original work is properly cited.

How to cite this article: Logan GG, Njoroge PK, Nyabola LO and Mweu MM. Determinants of preeclampsia and eclampsia among women delivering in county hospitals in Nairobi, Kenya [version 1; peer review: 2 not approved] F1000Research 2020, 9:192 https://doi.org/10.12688/f1000research.21684.1

First published: 18 Mar 2020, 9:192 https://doi.org/10.12688/f1000research.21684.1 


\section{Introduction}

Preeclampsia affects $2-10 \%$ of pregnant women globally and eclampsia $0.03-0.05 \%$. However, the overall prevalence of preeclampsia according to studies varies from $4.5 \%$ to $23 \%{ }^{2}$. Preeclampsia affects about $4 \%$ of pregnancies in the United States of America ${ }^{3}$. In Kenya, the incidence of preeclampsia is about $0.3 \%$ while the prevalence is $6.1 \%{ }^{5}$. Similarly in Ethiopia, the prevalence of preeclampsia is about $5 \%{ }^{6}$. In Nigeria, the prevalence of preeclampsia ranges between 2 and $16.7 \%^{7}$.

The maternal mortality ratio in Sub-Saharan Africa is estimated to be 510 maternal deaths per 100,00 live births ${ }^{8}$. Maternal and fetal complications in addition to maternal and fetal mortality are much greater in mothers with pre-eclampsia and eclampsia than those without ${ }^{2}$. Preeclampsia is the second top cause of maternal death globally, which may lead to grave maternal complications (stroke, eclampsia, and organ failure), and poor perinatal outcome for the fetus and infant especially intrauterine development restriction, low birth weight, and stillbirth ${ }^{9}$. Preeclampsia develops in $20 \%$ of first pregnancies and entails more than $40 \%$ of premature birth resulting from treatment ${ }^{2}$. About $98 \%$ of maternal, fetal, and neonatal death related to preeclampsia and eclampsia occur in low-income countries, with much of this mortality in South Asia and Sub-Saharan Africa ${ }^{10}$. Preeclampsia also accounts for increasing maternal \& perinatal/infant mortality, and it is a major cause of maternal mortality $15-20 \%$ in developed countries $^{11}$.

Preeclampsia and eclampsia are among the hypertensive disorders of pregnancy. About $13 \%$ of maternal mortality globally is due to hypertensive disorders of pregnancy and the number is even higher in developing countries with an estimate between $20-80 \%$ in Africa and Latin America ${ }^{1}$.

Many risk factors have been associated with preeclampsia/ eclampsia ${ }^{2}$. Nevertheless, a full account of the risk factors of preeclampsia/eclampsia has not been well established in the Kenyan population ${ }^{4}$. Therefore, this study was conducted to investigate some risk factors of preeclampsia/eclampsia namely; socio-demographic, reproductive and obstetric, clinical, behavioral and family history-related factors, with a view of informing policy, creating awareness, and formulating strategies to improve antenatal care and delivery services among women of reproductive age in Kenya.

\section{Methods}

Study design and setting

This was a hospital-based unmatched case-control study carried out at Nairobi County Hospitals' postnatal ward. This study design was chosen because it is appropriate for identifying risk factors associated with pre-eclampsia/eclampsia, which are latent conditions among gravid women.

This study was carried out at Mbagathi District Hospital (Kibra), Mama Lucy Kibaki Hospital (Embakasi Central), and Pumwani Maternity Hospital (Kamukunji) in Nairobi County,
Kenya; with a catchment population of 4.6 million people, $58 \%$ of which are slum dwellers. These are public county hospitals offering primary, secondary, and tertiary health care services to Nairobi residents and neighboring counties such as Kajiado, Kiambu and Machakos counties.

\section{Study population and eligibility of participants}

The study population was women of reproductive age (15-49 years) who have given birth at Nairobi County Hospitals and admitted to the postnatal ward from July-September, 2019. The controls and cases were selected from the study population-based outlined criteria for eligibility. A postnatal ward mother that met/satisfied the definition of a case or control and consented to participation was included. Those aged less than 18 years old were included in the study, but both the parent/guardian and patient were required to sign consent and assent forms, respectively. A postnatal ward mother that did not meet the definition of a case or control was excluded from the study.

\section{Case definition and recruitment}

A case was defined as a woman of reproductive age (15-49 years) admitted in postnatal wards having been diagnosed of preeclampsia (high blood pressure during pregnancy, $\geq 140 / 90 \mathrm{mmHg}$, plus proteinuria $\geq 300 \mathrm{mg} / 24$ hours or $\geq 1+$ dipstick) or eclampsia (high blood pressure during pregnancy, proteinuria plus generalized seizures) at Nairobi County Hospitals July- September, 2019. All cases that met the case definition were selected during the study period, July-September 2019, to obtain the required sample of 88 cases and the response rate was $100 \%$. Thus, each case was selected after the physician (medical officer or consultant obstetrician/ gynecologist) had made a diagnosis (preeclampsia/eclampsia) and client admitted to the postnatal ward.

\section{Control definition and recruitment}

Control was defined as a woman of reproductive age (15-49 years) admitted to the postnatal ward without preeclampsia/ eclampsia at Nairobi County Hospitals from July-September 2019. Controls were simple randomly sampled from a list of women admitted to each of the three hospitals' post-natal ward without preeclampsia/eclampsia which was recruited at the time of selection of the cases. A total of three controls for each case were selected by the time of selection to cases. The sampling frame was updated as per deliveries taking place in study hospitals from July-September 2019.

\section{Sample size determination}

The sample size of 352 participants (264 controls \& 88 cases) was determined as specified by Kelsey, Jennifer, and others ${ }^{12}$ for case-control studies as follow:

$$
\begin{aligned}
& n_{1}=\frac{\left(Z_{\alpha}+Z_{\beta}\right)^{2} \overline{p q}(r+1)}{r\left(p_{1}-p_{2}\right)^{2}}, \quad p_{1}=\frac{p_{2} O R}{1+p_{2}(O R-1)} \\
& \overline{\mathbf{p}}=\frac{\mathbf{p}_{1}+\mathbf{r} \mathbf{p}_{2}}{\mathbf{r}+\mathbf{1}}, \quad \overline{\mathbf{q}}=\mathbf{1}-\overline{\mathbf{p}} \\
& \mathbf{n}_{2}=\mathbf{r n}_{1}
\end{aligned}
$$




$$
\begin{aligned}
\mathrm{N}_{1} & =\frac{(1.96+0.84)^{2}(0.462887323)(0.537112677)(3+1)}{3(0.591549295-0.42)^{2}} \\
& =88.3 \text { or } \mathbf{8 8} \text { (cases) }
\end{aligned}
$$

$\mathrm{N}_{2}=\mathrm{rn}_{1}$

Total sample size $=n_{1}+n_{2}=88+264=\mathbf{3 5 2}$

$=3(88)$

$=264$ (controls)

Since the outcome is rare in the Kenyan population, the ratio of 3 controls to 1 case was used in calculating the sample size but still maintains the statistical power of the study; $\mathrm{N}_{1}$ is the number of cases and $\mathrm{N}_{2}$ is the number of controls. Furthermore, $\mathrm{P}_{1}$ is the proportion of cases exposed thus, was the proportion of women with pre-eclampsia/eclampsia that attend less than four antenatal clinic (ANC) visits; $\mathrm{P}_{2}$ is the proportion of controls exposed and this was the proportion of women without pre-eclampsia/eclampsia that attends less than four ANC visit, that was set at $42 \%{ }^{13} ; Z_{\alpha}(1.96)$ and $Z_{\beta}(-0.84)$ were the required values specifying the two-tailed confidence interval $(95 \%)$ and statistical power $(80 \%)$ desired respectively. The odds for attending less than four ANC visits-preeclampsia/ eclampsia association was been set at 2 (universally acceptable) and $r=3$, is the ratio of controls to cases. Given these figures, the desired sample size of 352 participants (88 cases and 264 controls) was computed.

\section{Study variables}

The dependent variable was pre-eclampsia/eclampsia status measured as a binary categorical variable. The independent variables of interest were maternal age, education, residence, marital status, occupation, ethnicity, religion, maternal age, age at first marriage, age at first pregnancy, number of antenatal care visit, time/trimester of first ANC visit, gravidity, parity, child sex, anaemia in pregnancy, urinary tract infection (UTI) in pregnancy, alcohol use, tobacco use, family history of hypertension, family history of diabetes, personal history of diabetes, personal history of hypertension, and use of traditional treatment or medicine. All of these explanatory variables were more or less potential confounders and a determination of which one is a confounder was made during analysis. A pretested structured interview questionnaire was used to collect primary data from postnatal mothers and a data abstraction tool was also used to collect some secondary data, both available as Extended data ${ }^{14}$.

\section{Ethical considerations}

The research was granted ethical clearance by Kenyatta National Hospital (KNH)-University of Nairobi (UON) Ethics and Research Committee (P426/05/2019) and the Nairobi City County Government - Public health division (Ref. No. NCC/ HRD/HRM/11/904/JWN/2019). Furthermore, written consent was obtained from the participants after they were informed about the nature of the study.

\section{Minimization of biases}

Before starting data collection, six research assistants (two for each of the three health facilities) were trained on the sampling technique for cases and controls and standard interview skills to reduce systemic error and interview bias. Research assistants were also trained to get information such as the number of antenatal care (ANC) visits, time/trimester of first ANC visit from the patient medical record using data abstraction tool in an attempt to reduce recall bias. Misclassification bias which could affect both cases and controls was minimized by including cases and controls determined by the obstetrician.

\section{Statistical analysis}

The filled questionnaires were first checked for completeness then followed by the entry of data collected from the field into Microsoft Excel spreadsheets, cleaned, formatted, coded and audited for quality and consistency using Epi-info software before exporting the dataset to Stata -version 14.0 computer programming software. Descriptive analysis was carried out, where, categorical variables were presented in percentages or proportions, whereas, continuous variables were presented in means and standard deviations. This was followed by bivariable mixed-effect logistic regression analysis and a multivariable mixed-effect logistic regression analysis using the significant variables $(p \leq 0.20)$ from the bivariable analysis. A modified Hosmer-Lemeshow goodness-of-fit test was carried out; after which, variables with $\mathrm{p} \leq 0.05$ were considered as factors associated with preeclampsia/eclampsia.

\section{Results and discussion}

Results

Socio-demographic characteristics of the study participants. The study participants were 352 , of whom 88 were cases and 264 were controls. Among the cases, preeclampsia accounted for $83(94.3 \%)$ and eclampsia $5(5.7 \%)$. This was a multicenter study conducted in Pumwani Maternity Hospital which had 196 participants $(55.7 \%)$, Mama Lucy Kibaki Hospital with 99 participants $(28.1 \%)$ and Mbagathi District Hospital with 57 participants $(16.2 \%)$. The distribution of study participants by study hospital is presented in Table 1; individual-level responses to questionnaire items are available as Underlying data

The mean maternal age of the study participants was 26.1 years $(\mathrm{SD}=5.5)$; the mean maternal age of controls being 26.1 years with a standard deviation 5.3 years (range: 18-41 years) and the mean maternal age of cases being 27.6 years with 5.9 standard deviation (range: 17-42). About $81 \%$ of cases and $83 \%$ of controls were mothers aged between 20 and 34 years old. Among the controls and cases, 71 (26.9\%) and 23 (26.1\%) had primary-level education, respectively, whereas $140(53.0 \%)$ of the controls and $40(45.5 \%)$ of cases had a secondary level of education. In terms of marital status, $80.7 \%$ of cases and $80.7 \%$ of controls were married. The majority of cases $49(55.7 \%)$ and controls $114(43.2 \%)$ had an occupation as housewife.

Concerning the county of residence, 247 (93.6\%) of controls and $86(97.7 \%)$ of cases were residents of Nairobi County. Mothers of Kenyan ethnicity accounted for $258(97.7 \%)$ of controls and $86(97.7 \%)$ of cases whereas, those of non-Kenyan ethnicity were $2(2.3 \%)$ of cases and $6(2.3 \%)$ of controls. Among the cases and controls, $97.7 \%$ and $97.0 \%$ were Christians respectively; whereas Muslim mothers represented 8 $(3.0 \%)$ controls and $2(2.3 \%)$ of cases. The socio-demographic factors of the study population are presented in Table 2. 
Table 1. Distribution of study participants by study hospital.

\begin{tabular}{|l|l|l|l|}
\hline Study hospital & $\begin{array}{l}\text { Controls } \mathbf{( n = 2 6 4 ) ,} \\
\mathbf{n}(\%)\end{array}$ & $\begin{array}{l}\text { Cases }(\mathbf{n}=\mathbf{8 8}), \\
\mathbf{n}(\%)\end{array}$ & Total, $\mathbf{n}(\%)$ \\
\hline Mama Lucy Kibaki & $74(28.0)$ & $25(28.4)$ & $99(28.1)$ \\
\hline Mbagathi District & $43(16.3)$ & $14(15.9)$ & $57(16.2)$ \\
\hline Pumwanity maternity & $147(55.7)$ & $49(55.7)$ & $196(55.7)$ \\
\hline
\end{tabular}

\begin{tabular}{|c|c|c|c|}
\hline Variable & Cases, n (\%) & Controls, n (\%) & Total, n (\%) \\
\hline \multicolumn{4}{|l|}{ Education Level } \\
\hline No education & $1(1.1)$ & $1(0.4)$ & $2(0.6)$ \\
\hline Primary education & $23(26.1)$ & $71(26.9)$ & $94(26.7)$ \\
\hline Secondary education & $40(45.5)$ & $140(53.0)$ & $180(51.1)$ \\
\hline Tertiary education & $24(27.3)$ & $52(19.7)$ & $76(21.6)$ \\
\hline \multicolumn{4}{|l|}{ Maternal Age } \\
\hline$<20$ & $4(4.55)$ & $19(7.2)$ & $23(6.5)$ \\
\hline $20-34$ & $71(80.7)$ & 220 (83.3) & $291(82.7)$ \\
\hline $35-49$ & $13(14.8)$ & $25(9.5)$ & $38(10.8)$ \\
\hline \multicolumn{4}{|l|}{ Marital status } \\
\hline Married & $71(80.7)$ & $213(80.7)$ & $284(80.7)$ \\
\hline Separated & $0(0.0)$ & $4(1.5)$ & $4(1.1)$ \\
\hline Single & $16(18.2)$ & $45(17.1)$ & $61(17.3)$ \\
\hline widowed & $1(1.1)$ & $2(0.8)$ & $3(0.9)$ \\
\hline \multicolumn{4}{|l|}{ Occupation } \\
\hline Salaried employee & $10(11.4)$ & $26(10.0)$ & $36(10.2)$ \\
\hline Housewife & $49(55.7)$ & $114(43.2)$ & $163(46.3)$ \\
\hline Merchant/business & $22(25.0)$ & $91(34.5)$ & $113(32.1)$ \\
\hline Other occupation & $7(8.0)$ & $33(12.1)$ & $40(11.4)$ \\
\hline \multicolumn{4}{|l|}{ County of residence } \\
\hline Nairobi & $86(97.7)$ & $247(93.6)$ & $333(94.6)$ \\
\hline Other counties & $2(2.3)$ & $17(6.4)$ & $19(5.4)$ \\
\hline \multicolumn{4}{|l|}{$\begin{array}{l}\text { Specific place of } \\
\text { residence }\end{array}$} \\
\hline Urban/estate & $42(47.7)$ & $143(54.2)$ & $185(52.6)$ \\
\hline Rural & $0(0.0)$ & $8(3.0)$ & $8(2.3)$ \\
\hline Informal settlement & 46 (52.3) & $113(42.8)$ & $159(45.2)$ \\
\hline \multicolumn{4}{|l|}{ Ethnicity } \\
\hline Kenyan & $86(97.7)$ & $258(97.7)$ & $344(97.7)$ \\
\hline Non-Kenyan & $2(2.3)$ & $6(2.3)$ & $8(2.3)$ \\
\hline \multicolumn{4}{|l|}{ Religion } \\
\hline Christian & $86(97.7)$ & $256(97.0)$ & $342(97.2)$ \\
\hline Muslim & $2(2.3)$ & $8(3.0)$ & $10(2.8)$ \\
\hline
\end{tabular}


The socio-demographic factors associated with preeclampsia/eclampsia. The socio-demographic factors hypothesized to significantly associate with preeclampsia/eclampsia include maternal age, maternal level of education, marital status, maternal occupation, maternal county of residence, and religion.

Compared to mothers aged less than 20 years, mothers 20-34 years of age were 1.5 times more likely to suffer preeclampsia/eclampsia $(\mathrm{OR}=1.5,95 \% \quad \mathrm{CI}=0.5-4.7, \mathrm{p}=0.451)$ whereas mothers aged 35-49 years were 2.5 times more likely to experience preeclampsia/eclampsia than mothers aged less than 20 years $(\mathrm{OR}=2.5,95 \% \mathrm{CI}=0.7-8.8, \mathrm{p}=0.163)$.

Postnatal mothers from government/private occupation were 1.8 times more likely to suffer from preeclampsia/eclampsia than those from other occupations $(\mathrm{OR}=1.8,95 \% \mathrm{CI}=0.6-5.4$, $\mathrm{p}=0.286$ ) whereas those that have an occupation as housewives were 2.0 times more likely to develop preeclampsia/eclampsia than other occupations. Similarly, mothers that have merchant/ business occupation were more likely to develop preeclampsia/ eclampsia than other occupations $(\mathrm{OR}=1.1,95 \% \mathrm{CI}=0.5-2.9$, $\mathrm{p}=0.789$ ).

Postnatal mothers from Nairobi County were at increased risk of preeclampsia/eclampsia compared to those from other counties $(\mathrm{OR}=3.0,95 \% \mathrm{CI}=0.7-13.1, \mathrm{p}=0.152)$. The associations between socio-demographic factors and preeclampsia/eclampsia are summarized in Table 3.

The reproductive and obstetric factors associated with preeclampsia/eclampsia

We hypothesized that reproductive and obstetrics factors likely associated with preeclampsia/eclampsia were maternal age, age at first marriage, age at first pregnancy, number of ANC visits, time/trimester of first ANC visit, gravidity, parity, and child-Sex.

\begin{tabular}{|c|c|c|c|c|c|}
\hline Variable & Cases, n (\%) & Controls, $n(\%)$ & $\chi^{2}$ & Crude OR $(95 \% \mathrm{Cl})$ & p-value \\
\hline \multicolumn{6}{|l|}{ Age group } \\
\hline$<20$ & $4(4.6)$ & $19(7.2)$ & \multirow[t]{3}{*}{2.44} & Ref & \\
\hline $20-34$ & $71(80.7)$ & 220 (83.3) & & $1.5(0.5-4.7)$ & 0.451 \\
\hline $35-49$ & $13(14.8)$ & $25(9.5)$ & & $2.5(0.7-8.8)$ & 0.163 \\
\hline \multicolumn{6}{|l|}{ Education Level } \\
\hline Up to Primary & $24(27.3)$ & $72(27.3)$ & \multirow[t]{3}{*}{2.47} & Ref & \\
\hline Secondary & $40(45.5)$ & $140(53.0)$ & & $0.9(0.5-1.5)$ & 0.603 \\
\hline Tertiary & $24(27.3)$ & $52(19.7)$ & & $1.4(0.7-2.7)$ & 0.34 \\
\hline \multicolumn{6}{|l|}{ Marital Status } \\
\hline Married & $71(80.7)$ & $213(80.7)$ & \multirow[t]{3}{*}{0.46} & $2(0.2-16.9)$ & 0.524 \\
\hline Separated/Widowed & $1(1.1)$ & $6(2.3)$ & & Ref & \\
\hline Single & $16(18.2)$ & $45(17.1)$ & & $2.1(0.2-19.1)$ & 0.498 \\
\hline \multicolumn{6}{|l|}{ Occupation } \\
\hline Salaried employee & $10(11.4)$ & $26(9.9)$ & \multirow[t]{3}{*}{5.34} & $1.8(0.6-5.4)$ & 0.286 \\
\hline House Wife & $49(55.7)$ & $114(43.2)$ & & $2.0(0.8-4.9)$ & 0.116 \\
\hline Merchant/Business & $22(25.0)$ & $91(34.5)$ & & $1.1(0.5-2.9)$ & 0.789 \\
\hline Others & $7(8.0)$ & $33(12.5)$ & & Ref & \\
\hline \multicolumn{6}{|l|}{ County of Residence } \\
\hline Nairobi & $86(97.7)$ & 247 (93.6) & \multirow[t]{2}{*}{2.05} & $3.0(0.7-13.1)$ & 0.152 \\
\hline Other County & $2(2.3)$ & $17(6.4)$ & & Ref & \\
\hline \multicolumn{6}{|l|}{ Specific Place of Residence } \\
\hline Informal/Rural Settlement & $46(52.3)$ & $121(45.8)$ & \multirow[t]{2}{*}{1.09} & Ref & \\
\hline Urban/Estate & $42(47.7)$ & $143(54.2)$ & & $1.3(0.8-2.1)$ & 0.295 \\
\hline \multicolumn{6}{|l|}{ Religion } \\
\hline Christians & $86(97.7)$ & $256(97.0)$ & \multirow[t]{2}{*}{0.14} & $0.7(0.2-3.6)$ & 0.712 \\
\hline Muslims & $2(2.3)$ & $8(3.0)$ & & Ref & \\
\hline
\end{tabular}


Nulliparous mothers were 4.8 times more likely to suffer from preeclampsia/eclampsia than multiparous mothers $(\mathrm{OR}=4.8$, 95\% $\mathrm{CI}=1.0-22.4, \quad \mathrm{p}=0.045)$ whereas primiparous mothers were 1.4 times more likely to develop preeclampsia/eclampsia than those that were multiparous $(\mathrm{OR}=1.4,95 \% \mathrm{CI}=0.9-2.3$, $\mathrm{p}=0.187$ ). Nulliparous mothers, though, were at increased risk of suffering preeclampsia/eclampsia; however, the association was not statistically significant in that the $95 \%$ confidence included 1 despite a p-value of $0.045 \quad(\mathrm{OR}=4.8, \quad 95 \%$ $\mathrm{CI}=1.0-22.4, \mathrm{p}=0.045)$. Therefore, there was no significant association between parity and development of preeclampsia and or eclampsia. Compared to mothers aged 20 years and above, teenage mothers were $30 \%$ less likely to develop preeclampsia/eclampsia $(\mathrm{OR}=0.7,95 \% \mathrm{CI}=0.4-1.3, \mathrm{p}=0.199)$.

Compared to mothers whose first antenatal care visit was in the first trimester of pregnancy, mothers whose first antenatal care visit was in the second and third trimesters were at reduced risk of preeclampsia/eclampsia $(\mathrm{OR}=0.8,95 \%$ $\mathrm{CI}=0.5-1.4, \mathrm{p}=0.473$ and $\mathrm{OR}=0.5,95 \% \mathrm{CI}=0.2-1.4, \mathrm{p}=0.191)$. Mothers whose age at first marriage was $<20$ years old were
$10 \%$ less likely to develop preeclampsia/eclampsia than those that were $\geq 20$ years old $(\mathrm{OR}=0.9,95 \% \mathrm{CI}=0.5-1.6, \mathrm{p}=0.659$ ) whereas mothers whose age at first pregnancy was $<20$ years old were 0.7 times more likely to develop preeclampsia/eclampsia than those that were $\geq 20$ years old $(\mathrm{OR}=0.7,95 \% \mathrm{CI}=0.4-1.3$, $\mathrm{p}=0.199$ ). The associations between reproductive and obstetric factors and preeclampsia/eclampsia are summarized in Table 4.

\section{The clinical factors associated with preeclampsia/eclampsia} Anemia and urinary tract infections in pregnancy were hypothesized to relate significantly with the occurrence of preeclampsia and eclampsia. Compared to mothers with a normal number of pus cells $(0-5 \mathrm{hpf})$ on admission for delivery, mothers with mild-moderate and severe UTI (6-10 hpf and $>10 \mathrm{hpf}$ ) in pregnancy on admission were 1.7 times more likely to develop preeclampsia/eclampsia (OR=1.7, 95\% $\mathrm{CI}=0.4-7.0, \mathrm{p}=0.454)$. Mothers with mild-moderate and severe levels (7-10.9 $\mathrm{g} / \mathrm{dl}$ and $<7 \mathrm{~g} / \mathrm{dl})$ of anemia on admission for delivery were 0.9 times as likely to suffer from preeclampsia/eclampsia than those with normal hemoglobin level $(\geq 11 \mathrm{~g} / \mathrm{dl}) ;(\mathrm{OR}=0.9,95 \% \mathrm{CI}=0.5-1.6, \mathrm{p}=0.625)$. Associations

Table 4. Association between reproductive and obstetric factors and preeclampsia/ eclampsia.

\begin{tabular}{|c|c|c|c|c|c|}
\hline Variable & Cases, n (\%) & Controls, n (\%) & $\chi^{2}$ & Crude OR $(95 \% \mathrm{Cl})$ & $\mathrm{p}$-value \\
\hline \multicolumn{6}{|l|}{ Age at First Marriage } \\
\hline$<20$ & $19(26.4)$ & $64(29.1)$ & \multirow[t]{2}{*}{0.19} & $0.9(0.5-1.6)$ & 0.659 \\
\hline$\geq 20$ & $53(73.6)$ & $156(70.9)$ & & Ref & \\
\hline \multicolumn{6}{|l|}{ Age at First Pregnancy } \\
\hline$<20$ & $24(27.3)$ & $89(33.7)$ & \multirow[t]{2}{*}{1.25} & $0.7(0.4-1.3)$ & 0.199 \\
\hline$\geq 20$ & $64(72.7)$ & $175(66.3)$ & & Ref & \\
\hline \multicolumn{6}{|l|}{ Number of ANC Visits } \\
\hline$<4$ & $39(44.3)$ & $106(40.2)$ & \multirow[t]{2}{*}{0.47} & $1.2(0.7-1.9)$ & 0.492 \\
\hline$\geq 4$ & $49(55.7)$ & $158(59.9)$ & & Ref & \\
\hline \multicolumn{6}{|c|}{ Time/Trimester First ANC Visit } \\
\hline Up to First trimester & $29(33.0)$ & $73(27.7)$ & \multirow[t]{3}{*}{1.78} & Ref & \\
\hline Second trimester & $53(60.2)$ & $162(61.4)$ & & $0.8(0.5-1.4)$ & 0.473 \\
\hline Third Trimester & $6(6.8)$ & $29(11.0)$ & & $0.5(0.2-1.4)$ & 0.191 \\
\hline \multicolumn{6}{|l|}{ Gravidity } \\
\hline Primigravida & $37(42.1)$ & $99(37.5)$ & \multirow[t]{2}{*}{0.57} & Ref & \\
\hline Multigravida & $51(58.0)$ & $165(62.5)$ & & $0.8(0.5-1.4)$ & 0.449 \\
\hline \multicolumn{6}{|l|}{ Parity } \\
\hline Nulliparous & $4(4.6)$ & $3(1.1)$ & \multirow[t]{3}{*}{5.08} & $4.8(1.0-22.4)$ & 0.045 \\
\hline Primiparous & $42(47.7)$ & $109(41.3)$ & & $1.4(0.9-2.3)$ & 0.187 \\
\hline Multiparous & $42(47.7)$ & $152(57.6)$ & & Ref & \\
\hline \multicolumn{6}{|l|}{ Child Sex } \\
\hline Male & $41(46.6)$ & 138 (52.3) & \multirow[t]{3}{*}{1.31} & $0.5(0.1-2.2)$ & 0.35 \\
\hline Female & $44(50.0)$ & $121(45.8)$ & & $0.6(0.1-2.6)$ & 0.505 \\
\hline Multi-sex & $3(3.4)$ & $5(1.9)$ & & Ref & \\
\hline
\end{tabular}


between clinical factors and preeclampsia/eclampsia are presented in Table 5.

The behavioural and family history-related factors associated with preeclampsia/eclampsia

Further, the relationships between alcohol use, tobacco use, traditional treatment use, diabetes, and hypertension with preeclampsia/eclampsia were assessed. History of diabetes and hypertension were personal and family history.

Postnatal mothers who used tobacco were 3.9 times more likely to develop preeclampsia/eclampsia than those who did not use tobacco $(\mathrm{OR}=3.9,95 \% \mathrm{CI}=1.0-14.9, \mathrm{p}=0.046)$. Postnatal mothers who used tobacco were at increased risk of suffering preeclampsia/eclampsia; however, the association was not statistically significant in that the $95 \%$ confidence included 1 despite a p-value of $0.046 \quad(\mathrm{OR}=3.9, \quad 95 \% \quad \mathrm{CI}=1.0-14.9$, $\mathrm{p}=0.046$ ). On the other hand, mothers with a personal history of hypertension were 6.3 times more likely to suffer from preeclampsia/eclampsia than those without a personal history of hypertension $(\mathrm{OR}=6.3,95 \% \mathrm{CI}=2.7-14.8, \mathrm{p}=0.001)$. In addition, there was a significant association between personal history of hypertension and development of preeclampsia/eclampsia $(p<0.001)$. The associations between behavioural and family history-related factors and preeclampsia/eclampsia are presented in Table 6.

Multivariable mixed-effect logistic regression on risk factors for preeclampsia/eclampsia. A multivariable mixed-effect logistic regression model was used to determine the effect of various socio-demographic, reproductive and obstetric, clinical, behavioral and family history-related factors. Only variables

Table 5. Association between clinical factors and preeclampsia/eclampsia status.

\begin{tabular}{|l|l|l|l|l|l|}
\hline Variable & Cases, $\mathbf{n}(\%)$ & Controls, $\mathbf{n}(\%)$ & $\chi^{\mathbf{2}}$ & Crude OR (95\% Cl) & $\mathbf{p - v a l u e ~}$ \\
\hline $\begin{array}{l}\text { Pus cells count on admission for delivery } \\
\text { Normal }\end{array}$ & $3(23.1)$ & $18(34.0)$ & 0.56 & Ref \\
\hline Mild-moderate and severe UTI in pregnancy & $10(76.9)$ & $35(66.0)$ & $1.7(0.4-7.0)$ & 0.454 \\
\hline \begin{tabular}{l} 
Haemoglobin level on admission for delivery \\
\hline Normal
\end{tabular} & $67(77.9)$ & $189(75.3)$ & 0.24 & Ref & \\
\hline Mild-Moderate and severe level of anaemia & $19(22.1)$ & $62(24.7)$ & & $0.9(0.5-1.6)$ & 0.625 \\
\hline
\end{tabular}

\begin{tabular}{|c|c|c|c|c|c|}
\hline Variable & Cases, n (\%) & Controls, n (\%) & $\chi^{2}$ & Crude OR $(95 \% \mathrm{Cl})$ & p-value \\
\hline \multicolumn{6}{|c|}{ Alcohol Use } \\
\hline YES & $8(9.1)$ & $17(6.4)$ & \multirow[t]{2}{*}{0.7} & $1.5(0.6-3.5)$ & 0.404 \\
\hline NO & $80(90.9)$ & 247 (93.6) & & Ref & \\
\hline \multicolumn{6}{|c|}{ Tobacco use } \\
\hline YES & $5(5.7)$ & $4(1.5)$ & \multirow[t]{2}{*}{4} & $3.9(1.0-14.9)$ & 0.046 \\
\hline NO & $83(94.3)$ & $260(98.5)$ & & Ref & \\
\hline \multicolumn{6}{|c|}{ Personal history of hypertension } \\
\hline YES & $16(18.2)$ & $9(3.4)$ & \multirow[t]{2}{*}{17.69} & $6.3(2.7-14.8)$ & $<0.001$ \\
\hline NO & $72(81.8)$ & 255 (96.6) & & Ref & \\
\hline \multicolumn{6}{|c|}{ Family history of hypertension } \\
\hline YES & $19(21.6)$ & $36(13.6)$ & \multirow[t]{2}{*}{3.12} & $1.7(0.9-3.2)$ & 0.078 \\
\hline NO & $69(78.4)$ & $228(86.4)$ & & Ref & \\
\hline \multicolumn{6}{|c|}{ Family history of diabetes } \\
\hline YES & $4(4.6)$ & $21(8.0)$ & \multirow[t]{2}{*}{1.13} & $0.6(0.2-1.7)$ & 0.287 \\
\hline NO & $84(95.5)$ & $243(92.1)$ & & Ref & \\
\hline \multicolumn{6}{|c|}{ Traditional Treatment use } \\
\hline YES & $4(4.5)$ & $16(6.1)$ & \multirow[t]{2}{*}{0.28} & $0.7(0.2-2.3)$ & 0.596 \\
\hline NO & $84(95.5)$ & 248 (93.9) & & Ref & \\
\hline
\end{tabular}


that reached $\mathrm{p} \leq 0.2$ from the bivariable analysis were moved forward for multivariable analysis. Those variables that are of interest from previous studies were also moved forward for multivariable analysis despite not meeting the stated threshold requirement.

From the best model, mothers with advanced age 35-49 years were 5.9 times more likely to develop preeclampsia/eclampsia when compared to those aged less than 20 years $(\mathrm{AOR}=5.9$, 95\% CI=1.1-33.3, p=0.042). Mothers who had an occupation as housewife were significantly more likely to suffer from preeclampsia/eclampsia compared to those with other occupations $(\mathrm{AOR}=3.1 ; 95 \% \mathrm{CI}: 1.1-8.8, \mathrm{p}=0.034)$.

Mothers that had less than four ANC visits were 1.8 times more likely to suffer preeclampsia/eclampsia; however, the association was not statistically significant in that the $95 \%$ confidence included 1 despite a p-value of 0.041 (AOR=1.8, 95\% $\mathrm{CI}=1.0-3.3, \mathrm{p}=0.041$ ). Compared to mothers who were multiparous, nulliparous and primiparous were significantly associated with increased risk of developing preeclampsia/eclampsia $(\mathrm{AOR}=7.5,95 \% \mathrm{CI}=1.5-37.5, \mathrm{p}=0.015)$ and $(\mathrm{AOR}=2.1,95 \%$ $\mathrm{CI}=1.1-4.2, \mathrm{p}=0.031$ ) respectively.

Mothers with preeclampsia/eclampsia were 7.1 times more likely to have personal history of hypertension comparing to their counterparts $(\mathrm{AOR}=7.1,95 \% \mathrm{CI}=2.6-19.3, \mathrm{p}=0.001)$. The associations between risk factors and preeclampsia/eclampsia are presented in Table 7.

\section{Discussion}

Women with preeclampsia/eclampsia were more likely to be $35-49$ years of age comparing to their counterparts (AOR=5.9, 95\% $\mathrm{CI}=1.1-33.3, \mathrm{p}=0.042$ ). This was concurrent with other studies that showed an increased risk in a similar age group $^{11,15,16}$. A study conducted in Iran has linked the obstetric danger of advanced maternal age to aging-mediated vascular damage $^{2}$. This is because as a woman gets advanced age, she is more likely to develop heart/blood vessel related problems chiefly due to the steady failure of compliance of said vessels that are mainly linked with the ageing of uterine blood vessels and arterial firmness. Thus, the reason why preeclampsia/eclampsia is more likely in older women is biologically plausible.

The odds of developing preeclampsia/eclampsia were 3.1 times higher in postnatal mothers with occupation as housewife comparing to mothers with other occupations (AOR=3.1, 95\% $\mathrm{CI}=1.1-8.8, \mathrm{p}=0.034)$. The association between occupation as housewife and preeclampsia/eclampsia was statistically significant. A similar finding was obtained from a study done in Nigeria ${ }^{17}$. This could be due to stress-related factors arising from low socio-economic status and low wealth index.

According to the results of our study, women who were nulliparous or primiparous were at increased risk of developing preeclampsia/eclampsia than those who were multiparous. This was concurrent with several studies that found the same findings $s^{1,11,18}$. Several hypotheses have linked nulliparity to a maternal immune maladaptation ${ }^{2}$. This is for the reason that nulliparity is due to early trophoblastic invasion and how the mother reacts to it. The breakdown or malfunction of the normal invasion of trophoblastic cells leads to maladaptation of the coiled arterioles, which are linked to the causation of preeclampsia ${ }^{1}$.

Mothers that attended less than four ANC visits were at increased risk of developing preeclampsia/eclampsia when compared with those that attended four or more ANC visits. This is comparable to a study conducted in Nigeria ${ }^{17}$. Longdistance to access health facility, limited knowledge about antenatal care (ANC) services coupled with low socio-economic status could possibly be responsible for postnatal mothers not meeting the WHO recommended four or more ANC visits; a situation which could predispose mothers to obstetric complications such as preeclampsia and eclampsia. In this study however, the association between a number of ANC visits and the outcome (preeclampsia/eclampsia) was not statistically significant in that the $95 \%$ confidence included 1 despite a p-value of $0.041(\mathrm{AOR}=1.8 ; 95 \% \mathrm{CI}: 1.0-3.3, \mathrm{p}=0.041)$.

The study results found out that anemia and UTI in pregnancy were not significantly associated with preeclampsia/eclampsia; however, this finding contradicts studies conducted in Egypt, Sudan, and by $\mathrm{WHO}^{19-21}$.

Women with personal history of hypertension were more likely to suffer from preeclampsia/eclampsia compared with their counterparts (AOR=7.1, 95\% $\mathrm{CI}=2.6-19.3, \mathrm{p}=0.001)$. A similar finding was found in a study conducted in Nigeria ${ }^{17}$. It is probable that lifestyle modifications/behavioral factors are the reason for influencing women to an increased threat of preeclampsia/eclampsia. For instance, mothers taking-in an unhealthy diet; eating food high in fats and carbohydrates could increase their triglyceride levels, narrowing blood flow, which may predispose them to develop hypertensive disorders in pregnancy.

Limitations of the study. This study had some limitations. First, not all admission for delivery had their hemoglobin level (337 out of 352 study participants) and urinary pus cells count (only 66 out of 352) recorded in the study hospitals, therefore; if this study was repeated in other facilities with better recording of lab results of maternal admission, then the findings could be different. Secondly, there might have been recall bias regarding some factors such as the specific traditional treatment use and purpose of using the said treatment. Lastly, the hospital-based approach included only women attending the study hospitals.

\section{Conclusions}

This study indicated that a personal history of hypertension, older/advanced maternal age (35-49 years), occupation, and parity (nulliparous/primiparous) were factors significantly associated with preeclampsia/eclampsia. In this study, only 66 out of 352 participants $(18.8 \%)$ had their urinary pus cells recorded on admission for delivery and whether UTI in pregnancy is actually not associated with preeclampsia/eclampsia 


\begin{tabular}{|c|c|c|c|c|}
\hline Variable & Cases, n (\%) & Controls, n (\%) & Adjusted OR $(95 \% \mathrm{Cl})$ & p-value \\
\hline \multicolumn{5}{|l|}{ Age group } \\
\hline$<20$ & $4(4.6)$ & $19(7.2)$ & Ref & \\
\hline 20-34 & $71(80.7)$ & 220 (83.3) & $2.2(0.5-8.8)$ & 0.28 \\
\hline $35-49$ & $13(14.8)$ & $25(9.5)$ & $5.9(1.1-33.3)$ & 0.042 \\
\hline \multicolumn{5}{|l|}{ Occupation } \\
\hline Salaried employee & $10(11.4)$ & $26(9.9)$ & $2.1(0.6-7.5)$ & 0.241 \\
\hline Housewife & $49(55.7)$ & $114(43.2)$ & $3.1(1.1-8.8)$ & 0.034 \\
\hline Merchant/Business & $22(25.0)$ & $91(34.5)$ & $1.5(0.5-4.6)$ & 0.469 \\
\hline Others & $7(8.0)$ & $33(12.5)$ & Ref & \\
\hline \multicolumn{5}{|l|}{ County of residence } \\
\hline Nairobi & $86(97.7)$ & 247 (93.6) & $2.6(0.6-12.4)$ & 0.224 \\
\hline Other Counties & $2(2.3)$ & $17(6.4)$ & Ref & \\
\hline \multicolumn{5}{|l|}{ Age at first pregnancy } \\
\hline$<20$ & $24(27.3)$ & $89(33.7)$ & $1.05(0.5-2.1)$ & 0.902 \\
\hline$\geq 20$ & $64(72.7)$ & $175(66.3)$ & Ref & \\
\hline \multicolumn{5}{|l|}{ Number of ANC visits } \\
\hline$<4$ & $39(44.3)$ & $106(40.2)$ & $1.8(1.0-3.3)$ & 0.041 \\
\hline$\geq 4$ & $49(55.7)$ & $158(59.9)$ & Ref & \\
\hline \multicolumn{5}{|l|}{ Time/trimester first ANC visit } \\
\hline Up to First trimester & $29(33.0)$ & $73(27.7)$ & Ref & \\
\hline Second trimester & $53(60.2)$ & $162(61.4)$ & $0.9(05-1.7)$ & 0.74 \\
\hline Third Trimester & $6(6.8)$ & $29(11.0)$ & $0.5(0.1-1.6)$ & 0.214 \\
\hline \multicolumn{5}{|l|}{ Parity } \\
\hline Nulliparous & $4(4.6)$ & $3(1.1)$ & $7.5(1.5-37.5)$ & 0.015 \\
\hline Primiparous & $42(47.7)$ & $109(41.3)$ & $2.1(1.1-4.2)$ & 0.031 \\
\hline Multiparous & $42(47.7)$ & $152(57.6)$ & Ref & \\
\hline \multicolumn{5}{|c|}{ Haemoglobin level on admission for delivery } \\
\hline Normal & $67(77.9)$ & $189(75.3)$ & Ref & \\
\hline $\begin{array}{l}\text { Mid-Moderate level anaemia and } \\
\text { severe }\end{array}$ & $19(22.1)$ & $62(24.7)$ & $0.9(0.5-1.9)$ & 0.968 \\
\hline \multicolumn{5}{|l|}{ Tobacco use } \\
\hline YES & $8(9.1)$ & $17(6.4)$ & $1.7(0.4-7.8)$ & 0.518 \\
\hline NO & $80(90.9)$ & $247(93.6)$ & Ref & \\
\hline \multicolumn{5}{|l|}{ Personal history of hypertension } \\
\hline YES & $16(18.2)$ & $9(3.4)$ & $7.1(2.6-19.3)$ & $<0.001$ \\
\hline NO & $72(81.8)$ & $255(96.6)$ & Ref & \\
\hline \multicolumn{5}{|l|}{ Family history of hypertension } \\
\hline YES & $4(4.6)$ & $21(8.0)$ & $1.2(0.6-2.5)$ & 0.633 \\
\hline NO & $84(95.4)$ & $243(92.0)$ & Ref & \\
\hline
\end{tabular}


needs further investigation. Anemia in pregnancy was $10 \%$ less likely to develop preeclampsia/eclampsia.

Based on the study findings, this study makes the following recommendations to policymakers, county government, hospital management teams, and other relevant institutions:

1. Health Workers in Maternal and Child Health units of health facilities should emphasize the risk factors for preeclampsia and/or eclampsia to pregnant and postnatal mothers during their health talks in the health facilities. These messages should be extended to other pregnant and postnatal mothers in the catchment areas of the health facilities through Community Health Workers.

2. Maternity In-charges should ensure that urinary pus cell count and hemoglobin level for pregnant women are ordered and results recorded in the admission notes for delivery.

3. That future studies should investigate the association between UTI in pregnancy and preeclampsia/eclampsia in a multi-county study.

\section{Data availability}

\section{Underlying data}

Harvard Dataverse: Replication data for: Determinants of preeclampsia and eclampsia among women delivering in county hospitals in Nairobi, Kenya: https://doi.org/10.7910/DVN/ BYFL3 $\mathrm{J}^{14}$

This project contains the following underlying data:

- Logan preeclampsia dataset Final. (Study dataset)

- Logan preeclampsia dofile Final2 (do file code for Determinants-Preeclampsia/ eclampsia identification).

\section{Extended data}

Harvard Dataverse: Replication data for: Determinants of preeclampsia and eclampsia among women delivering in county hospitals in Nairobi, Kenya: https://doi.org/10.7910/DVN/ BYFL3J ${ }^{14}$.

This project contains the following extended data:

- Logan Interview Questionnaire \& Data Abstarction Tool. (Questionnaire and data abstraction tool used in this study.)

Data are available under the terms of the Creative Commons Zero "No rights reserved" data waiver (CC0 1.0 Public domain dedication).

\section{Acknowledgments}

We would like to acknowledge and thank the School of Public Health, College of Health Sciences/University of Nairobi for providing all assistance requested. Special thanks go to the members of the Kenyatta National Hospital-University of Nairobi Ethics and Research Committee and the Nairobi City County Government - Public Health Division for granting me the approval to conduct this research. We are indebted to the management and staff of Pumwani, Mama Lucy Kibaki and Mbagathi hospitals for allowing us to conduct this study within their facilities. Our appreciation goes to the Government of Liberia (GOL), the Republic of Liberia for funding this research and the entire study in Kenya.

Lastly, we wish to acknowledge and thank all the postnatal mothers who participated in this study. Their excitement and willingness to fill the questionnaires made the completion of this research an enjoyable experience. Furthermore, special thanks to the research assistants and data entry clerks who helped us in collecting and entering data.
1. Wandabwa J, Doyle $\mathrm{P}$, Kiondo $\mathrm{P}$, et al.: Risk factors for severe pre-eclampsia and eclampsia in Mulago Hospital, Kampala, Uganda. East Afr Med J. 2010; 87(10): 415-24.

PubMed Abstract

2. Kahnamouei-aghdam F, Amani F, Hamidimoghaddam S: Prevalence of preeclampsia and eclampsia risk factors among pregnant women, 2011-2013. Int $\mathrm{J}$ Adv Med. 2015; 2(2): 128-32.

Publisher Full Text

3. US Preventive Services Task Force, Bibbins-Domingo K, Grossman DC, et al:: Screening for Preeclampsia: US Preventive Services Task Force Recommendation Statement. JAMA. 2017; 317(16): 1661-1667. PubMed Abstract | Publisher Full Text

4. Itoh M, Were F, Owidhi M, et al.: Incidence of Pregnancy-Associated Hypertension and Preeclampsia in a cohort of Kenyan Women. Annals of Gynecology and Obstetrics. 2017; 1(1): 3-4.

Publisher Full Text

5. Otieno DAN: FACTORS CONTIBUTING TO ADVERSE OUTCOMES OF PREECLAMPSIA AMONG PREGNANT WOMEN ATTENDING ANTENATAL CLINICS

\section{IN KIBERA SLUMS, NAIROBI. 2012}

Reference Source

6. Wagnew M, Dessalegn M, Worku A, et al:: Trends of preeclampsia/eclampsia and maternal and neonatal outcomes among women delivering in addis ababa selected government hospitals, Ethiopia: a retrospective cross-sectional study. Pan Afr Med J. 2016; 25(Suppl 2): 12.

PubMed Abstract | Free Full Text

7. Osungbade KO, Ige OK: Public health perspectives of preeclampsia in developing countries: implication for health system strengthening. $J$ Pregnancy. 2011; 2011: 481095.

PubMed Abstract | Publisher Full Text | Free Full Text

8. Kirigia JM, Muthuri RD, Nabyonga-Orem J, et al: Counting the cost of child mortality in the World Health Organization African region. BMC Public Health. 2015; 15(1): 1103

PubMed Abstract | Publisher Full Text | Free Full Text

9. US Preventive Services Task Force, Grossman DC, Bibbins-Domingo K et al: Behavioral Counseling to Promote a Healthful Diet and Physical Activity for Cardiovascular Disease Prevention in Adults Without Cardiovascular Risk 
Factors: US Preventive Services Task Force Recommendation Statement. JAMA. 2017; 318(2): 167-174.

PubMed Abstract | Publisher Full Text

10. Goldenberg RL, Jones B, Griffin JB, et al.: Reducing maternal mortality from preeclampsia and eclampsia in low-resource countries--what should work? Acta Obstet Gynecol Scand. 2015; 94(2): 148-155. PubMed Abstract | Publisher Full Text

11. Shamsi U, Saleem S, Nishter N: Epidemiology and risk factors of preeclampsia; an overview of observational studies. Al Ameen J Med Sci. 2013; 6(4): 292-300. Reference Source

12. Kelsey JL, Whittemore AS, Evans AS, et al: Methods in observationa epidemiology. Monographs in Epidemiology and Biostatistics. 1996. Reference Source

13. Demographic K: Health Survey (2014 KDHS). 2014 Reference Source

14. Logan G: Replication Data for: Determinants of preeclampsia and eclampsia among women delivering in county hospitals in Nairobi, Kenya. Harvard Dataverse, V1, 2020. http://www.doi.org/10.7910/DVN/BYFL3J

15. Tessema GA, Tekeste A, Ayele TA: Preeclampsia and associated factors among pregnant women attending antenatal care in Dessie referral hospital, Northeast Ethiopia: a hospital-based study. BMC Pregnancy Childbirth. 2015; 15(1): 73.

Publisher Full Text
16. Wikström AK, Stephansson $O$, Cnattingius $S$ : Tobacco use during pregnancy and preeclampsia risk: effects of cigarette smoking and snuff. Hypertension. 2010; 55(5): 1254-1259

PubMed Abstract | Publisher Full Text

17. Guerrier G, Oluyide B, Keramarou M, et al.: Factors associated with severe preeclampsia and eclampsia in Jahun, Nigeria. Int J Womens Health. 2013; 5 509-13.

PubMed Abstract | Publisher Full Text | Free Full Text

18. Grum T, Seifu A, Abay M, et al.: Determinants of pre-eclampsia/Eclampsia among women attending delivery Services in Selected Public Hospitals of Addis Ababa, Ethiopia: a case control study. BMC Pregnancy Childbirth. 2017; 17(1): 307.

PubMed Abstract | Publisher Full Text | Free Full Text

19. Ali AA, Rayis DA, Abdallah TM, et al.: Severe anaemia is associated with a higher risk for preeclampsia and poor perinatal outcomes in Kassala hospital, eastern Sudan. BMC Res Notes. 2011; 4(1): 311

PubMed Abstract | Publisher Full Text | Free Full Text

20. El-Moselhy EA, Khalifa HO, Amer SM, et al.: Risk factors and impacts of preEclampsia: an epidemiological study among pregnant mothers in Cairo, Egypt. Journal of American Science. 2011; 7(5): 311-323. Reference Source

21. Bilano VL, Ota E, Ganchimeg T, et al.: Risk factors of pre-eclampsia/eclampsia and its adverse outcomes in low- and middle-income countries: a WHO secondary analysis. PLOS One. 2014; 9(3): e91198.

PubMed Abstract | Publisher Full Text | Free Full Text 


\section{Open Peer Review}

\section{Current Peer Review Status: $\mathrm{X} X$}

\section{Version 1}

Reviewer Report 19 October 2021

https://doi.org/10.5256/f1000research.23904.r96070

(C) 2021 Mayrink J. This is an open access peer review report distributed under the terms of the Creative Commons Attribution License, which permits unrestricted use, distribution, and reproduction in any medium, provided the original work is properly cited.

\section{Jussara Mayrink}

Federal University of Minas Gerais, Minas Gerais, Brazil

Dear authors, there are some suggestions I have about your study:

\section{Abstract:}

Be careful with preeclampsia concept, which is not exclusively linked to proteinuria anymore. Methods section can be more concise and in the sentence "(...) multivariable mixed-effect logistic regression analysis using the significant variables from bivariable analysis (...)" I am not sure about the significant variables. Where are they?

\section{Introduction:}

I missed the justification for the study. Why is it important to describe preeclampsia population from Nairobi, compared to the non-exposed group? In my opinion, authors should establish a link with preeclampsia prophylaxis, addressing social context and impossibility to perform laboratory markers to screen high-risk population.

\section{Methods:}

Case definition and recruitment: Since 2014 we recommend a "new" and "broader" concept of preeclampsia, which goes beyond the combination of hypertension and proteinuria. Thus, please, try to use other references. As this is a case-control study, it would be interesting adding some information, as the onset of preeclampsia, for instance. Interesting information is the criteria to diagnose preeclampsia.

Study design: I am afraid this is not a case-control study. The researches have looked to the information about cases and not-cases of preeclampsia and eclampsia. And, at the end, you perform a comparison between them on regard some characteristics. This is not a casecontrol study.

\section{Results and discussion:}

Dear authors, every time you put a result without statistical significance you must add this information. Another comment is: There are too many tables! 
Is the work clearly and accurately presented and does it cite the current literature? Partly

Is the study design appropriate and is the work technically sound?

Partly

Are sufficient details of methods and analysis provided to allow replication by others? Yes

If applicable, is the statistical analysis and its interpretation appropriate? Yes

Are all the source data underlying the results available to ensure full reproducibility? Yes

Are the conclusions drawn adequately supported by the results?

Yes

Competing Interests: No competing interests were disclosed.

Reviewer Expertise: preeclampsia, high risk pregnancy, maternal mortality, near miss

I confirm that I have read this submission and believe that I have an appropriate level of expertise to state that I do not consider it to be of an acceptable scientific standard, for reasons outlined above.

Reviewer Report 06 July 2020

https://doi.org/10.5256/f1000research.23904.r65550

(C) 2020 Adam I. This is an open access peer review report distributed under the terms of the Creative Commons Attribution License, which permits unrestricted use, distribution, and reproduction in any medium, provided the original work is properly cited.

\section{Ishag Adam}

Faculty of Medicine, University of Khartoum, Khartoum, Sudan

The authors investigated an important topic "preeclampsia". I have some points that need to be addressed.

\section{Abstract:}

No need to have details of statistic methods in the abstract.

Methods:

It is not clear if these cases were mild or severe cases or if these were early or late preeclampsia. 
More elaborations are needed because the risk factors are different in the different types of preeclampsia.

There many factors that were not investigated e.g. anemia, malaria, body mass index, blood groups.

I think all this information could be added to your work and you might have different results.

\section{Sample size:}

It is advisable to consider the difference between the two groups using the least prevalent one e.g. smoking or alcohol such as 3.0 vs $2 . \%$ and not using the high one as you used antenatal care.

\section{Statistics:}

I do not think you used mix model I think you used logistic regression models.

In the methods, you mentioned that variables with $p \leq 0.2$ were entered in the model. Then later on you contradict yourself and you mentioned that variables that were shown to be associated with preeclampsia were entered in the model regardless of their $\mathrm{P}$ value.

\section{Results:}

All your tables can be summarized in two tables only:

Table 1 all comparing all variables between preeclampsia and controls

Table 2 logistic regression with non -adjusted and adjusted values

Is the work clearly and accurately presented and does it cite the current literature? Yes

Is the study design appropriate and is the work technically sound? Yes

Are sufficient details of methods and analysis provided to allow replication by others? Partly

If applicable, is the statistical analysis and its interpretation appropriate? Partly

Are all the source data underlying the results available to ensure full reproducibility? Yes

Are the conclusions drawn adequately supported by the results? Partly

Competing Interests: No competing interests were disclosed. 
Reviewer Expertise: Maternal and perinatal epidemiology

I confirm that I have read this submission and believe that I have an appropriate level of expertise to state that I do not consider it to be of an acceptable scientific standard, for reasons outlined above.

The benefits of publishing with F1000Research:

- Your article is published within days, with no editorial bias

- You can publish traditional articles, null/negative results, case reports, data notes and more

- The peer review process is transparent and collaborative

- Your article is indexed in PubMed after passing peer review

- Dedicated customer support at every stage

For pre-submission enquiries, contact research@f1000.com 